\title{
Analysis the Effect of Service Quality, Customers Value, Customer Satisfaction and Customer Trust on Corporate Image
}

\author{
Helwen Heri \\ Universitas Lancang Kuning, Pekanbaru, Riau, Indonesia
}

\begin{abstract}
The aim of this study was to analyze the impacts of service quality toward customer trust as well as to prove whether corporate image, customer satisfaction and customer value mediate the relationship between service quality and customer trust. Several findings of this study were: the improvement of services quality did not directly affect customer trust; improvement of service should be able to satisfy customers or improve customer value; furthermore, customer satisfaction would improve customer trust as well as customer value. It was also proven that customer satisfaction mediated the relationship between corporate image and customer trust and mediated customer value and customer trust.
\end{abstract}

Keywords: service quality, customer value, customer satisfaction, corporate image and customer trust

\section{Introduction}

Customer trust is seen as a key factor for the creation of a relationship between providers and users of services / products. Lau and Lee (1999), if one party believes the other party will lead to positive behavior towards the next relationship. Anderson and Narus (1990) confidence arising from each party are positive, confidence will be enhanced. Doney and Cannon (1997) associated with this belief, each party must also have the ability to continue the relationship into a positive relationship and provide benefits for the continuation of the relationship in the future. Trust is built based on the ability of a party to predict the behavior of business partners in the future as to the accuracy of his so far in fulfilling the promise he had made.

As a company that produces products in the form of clean water, consumer confidence for the Regional Water Company (PDAM) is an important aspect in achieving the objectives of the company. However, customer trust is highly influenced by aspects of services related to products and services produced.

As a company organizing a good public, consistently and sustainable local water company (PDAM) in Riau Province providing services to customers because water is a basic need in everyday life and have important role in supporting the prosperity and welfare of the community. Although nature has provided water in sufficient quantities, but the growing population and increased activity has changed the shape and balance of water in nature. Most of the water that is available is no longer suitable for consumption directly and require processing (special treatment) to prevent water from natural and healthy for consumption. In order to maintain the viability of the company and to be able to serve the needs of customers of drinking water in adequate amounts, consistent and sustainable, PDAM are managed based on the principles of economic enterprise (business).

Various issues related to service PDAM that come to the surface is still not maximal service. The problems faced by PDAM in Indonesia, including in Riau Province is generally very similar among them: the continuity of unstable water, the quality of human resources is low, the water quality is bad and so forth and so can not meet customer expectations and the impact on the loss of customers' trust PDAM. This triggers a customer complaint in receiving the service.

Public complaints against bad service PDAM occurred in some areas in the province of Riau. The increase in the basic rate of water that is not followed by the quality of water produced in Indragiri Hilir, bad service at PDAM Tirta Siak so customers unsubscribe 4000, PDAM Tirta Dharma failure to meet public demand Bengkalis Bengkalis. Water quality and poor service quality impacts adversely PDAM in Riau Province.

The focus of this research is a factor of the quality of service received by the customer PDAM still not up and caused many complaints due to the low quality of the services provided by PDAM. The impact of the low quality of those services produce a negative image in the minds of customers and impact on customer satisfaction, corporate image, customer value and customer confidence.

\section{Literature Review}

Quality simply as suitability for use, product features meet the needs of consumers and free of deficiencies. Quality is the overall traits and characteristics of a product or service to the ability to meet the needs that have been determined or latent. Implies quality meets or exceeds expectations about the pace of time, work accuracy, speed of response, and performance (Parasuraman, et al., 1985). Quality of service is a comparison between services felt (perceived) customers with the quality service they expect. 
If service quality perceived equal to the quality of service they expect quality is said. If measured by the ratio between service quality perceived by the expected service quality, quality of service is said to be satisfactory if the ratio is one, and if the ratio is more than one qualified to say.

\section{Service quality}

Service Quality has become the most studied topics in marketing studies and debate and controversy among researchers associated with the conceptualization and measurement of quality of service (Choi, et al., 2004). This is because the service characteristics that are not real and assess customer service quality is subjective, so by Parasuraman et al., (1985) is more difficult to measure than the quality of goods and customers.

Quality of care is inextricably linked with the customer. Good service quality in customer perception can only be achieved when customer expectations of the product can be satisfied or more than customers expect. Quality of service, if managed properly, contribute positively to the realization of customer satisfaction and customer loyalty (Kotler, 2008). Quality of care giving services plus the value in the form of a special motivation for our customers. This kind of emotional bond allows the company to understand carefully the specific expectations and needs of customers. Service quality are important factors that could affect customer satisfaction of consumers.

Choi et al., (2004) states the quality of service and value of the service has a direct and significant impact on customer satisfaction. The definition of the value of the service used in the context of research similar to that proposed by Zeithaml (2000) where the value of the service is the overall perception of the customer based on the perception received and what has been given. Heskett et al., (1990) in Dedeke (2003) defines the value of the service as the quality of service divided by the product of all the costs incurred to obtain the service.

Parasuraman, et al., (1985) which was later revised in 1988 using disconfirmation paradigm. Based on the concept, the quality of service represents the difference between the value received with the expected value in five dimensions:

1. Reliability: the ability to deliver services reliably and accurately

2. Responsiveness: the ability to be able to help customers and provide services quickly

3. Assurance (collateral): the ability to provide services with reliable, free from danger, polite and skillful.

4. Empathy: the ability to provide the service as a communicative, give personal approach and understanding of customer needs.

5. Tangibles: the condition of the physical facilities surrounding the delivery of services.

\section{Customer value}

Conceptualization value becomes very important for research in the fields of marketing, as revealed by Gallarza and Saura (2006) as follows:

1. The concept of customer value is based on the development of two important dimensions of consumer behavior, namely economic (value associated with the perception of the price through what is called the transaction value) and psychological (what actually influences the choice of the products: the emotional aspect or more on cognitive /rational).

2. methodological, construct value will help explain the different areas of consumer behavior, such as product selection, purchase intent, repeat purchases.

3. The value can not be released in relation to construct the main consumer behavior, such as quality of service and satisfaction.

Zeithaml et al., (1988), as the value of the overall assessment of the use of products based on what is acceptable and what is given. There are four definitions of value service products that can be identified, namely: (1) the value of the service is a low price; (2) the value of any service is desired in the product; (3) value of service is service quality in getting the price paid; and (4) value of service is what you get and what is given. The value of the service is a combination of benefits and sacrifices that occur when a customer uses a product or service to meet specific needs. Customers will receive the value of the service in accordance with the utility provided by the combination of attributes is reduced disutility represented by the price that has been paid. Consumer perception of the value of the services affected by differences in customer tastes, and customer characteristics.

\section{Corporate image}

The company's image constructed by the technical quality is what the customer received from previous experiences and functional quality that is the way how the service provided to customers (Grönroos, 1984). Customers who perceive a company with a good image would be forced to buy products from the company. 
Corporate image is another important factor in the overall evaluation of the service. Consumers are not just buying a product, but they buy 'attitude'. Overall the image attached to the company will be considered by consumers to determine which products will be purchased. Consumer behavior in the purchase will be affected by the company's image. Imagery is defined by Dichter (in Suhartanto, 2001) as an impression of a person about an object or item as a whole. While Norman (in Suhartanto, 2001) looked at the image as a model that indicates a person's beliefs about the phenomenon or situation. So that the company's image can be defined as the perception of companies featured in customer retention and acts as a filter that affects the perception of the organization's operations (Lai et al., 2008).

Imagery is an important aspect of the organization's ability to maintain market position. The image of the company has been identified as an important factor in the overall evaluation of the company (Bitner, 1990) and entered into the mind when they hear the name of the company (Nguyen et al., 2006). The company's image is the result of the interactions, experiences, beliefs, and feelings of the people who know about the company. Dobni and Zinkhan (1990) in Chong (2008) concluded that the image formed by the interpretation of rational and emotional perception. According to Kennedy (1997) in Chong (2008) there are two main components of the corporate image: functional and emotional. Functional components associated with the real characteristics that can be easily measured, such as the physical environment offered by the hotel; the emotional component associated with psychological dimensions that are manifested by feelings and attitudes towards the organization.

\section{Customer satisfaction}

Customer satisfaction has been seen as a basic determinant of long-term consumer behavior and marketing study area has become increasingly attracted the attention of researchers. Furthermore, Anderson and Fornell (In Shih, 2006) put customer satisfaction as a central point for assessing past performance and predict future financial performance and as a matter of urgency to change the old way of doing business and finding ways to acquire and retain customers. Andreassen and Lindestad (1997) say that customer satisfaction is related to the subjective evaluation of emotions. The role of the company's image not only in attracting new customers, but also retain customers that are not satisfied. Pizam and Ellis (1999) stated that customer satisfaction is very important for the survival of the company. Customer satisfaction is not a universal phenomenon and not everyone gets the same customer satisfaction of the same experience. The reason is that each different customer needs, goals and past experiences that affect their expectations.

Satisfaction as a customer responses regarding the evaluation of satisfaction as the customer response regarding the evaluation of the perception of incompatibility between prior expectations and actual performance of products after consumption. Bitner and Drew (in Bloemer et al., 1997) introduced the distinction between satisfaction when using the service and overall satisfaction with the service, where the latter is associated with a number of previous experience in a shorter period of time.

\section{Customers trust}

Trust is the key variable in the exchange network between the company and its partners (Morgant \& Hunt, 1994). The psychology of belief is a belief and a will or may be called as a tendency of behavior (Moorman et al., 1992). Mutual trust is the belief of both parties that between them will not exploit the weaknesses of the other party. In trust there is an element of risk that is typically associated with the decision taken. Sources of these risks are the desire and willingness of the parties involved to act accordingly. In general, for both manufacturing and service industries, the basis of long-term relationships with existing customers on consumer confidence in the company. In business, trust is seen as one of the antecedent relationship. Researchers have established that trust is important to establish and maintain long-term relationships (Singh \& Sirdeshmukh, 2000). Morgan and Hunt (1994) states that there is confidence only if one of the parties have confidence in the reliability and integrity. While Moorman et al., (1993) define trust as the dependence of one of the parties have confidence. Anderson and Narus (1990) concluded that if one party believes that the actions of the other party will bring positive results to the first party, the trust can be developed.

Berry (1999) in Jasfar (2005) propose a model that explains the factors that become the foundation of formation of long-term relationships based on trust. In this model, explained the factors on which to base the creation of confidence in the company that is the perception of the skill (competence) and fairness (fairness) company directly to have a role in fostering or instill a sense of trust (sense of trust). Two of these factors is the foundation that creates a sense of trust employees, business partners and consumers. Smith and Bolton (1998) also found that the company's competency become prominent in forming a trust (trust formation). Studies on the relationship of sales partners who do support the concept of trust in three dimensions (a three-dimensional conceptualization of trustworthiness) the character (character), competence (competence), and judgment (judgment). Knowing that the competence of a service not easily found, the customer would remember it when they find it. Competence of a service form customers confidence in a company's capacity to hold promise. 


\section{Conceptual Framework}

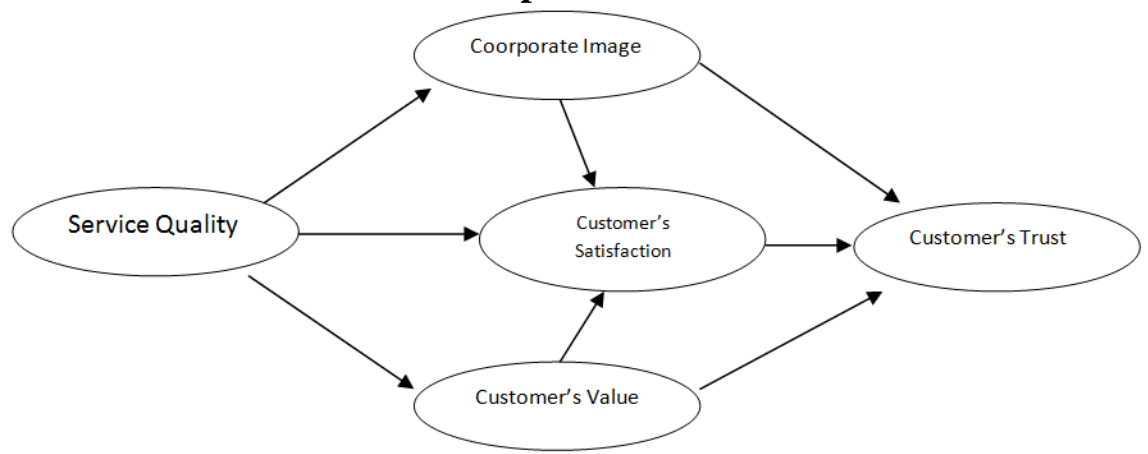

\section{Hypothesis}

Based on the research background and the conceptual framework of research, the research hypothesis can be formulated as follows.

H1: The better the service quality provided will be enhance the company's image.

$\mathrm{H} 2$ : The better the service quality provided will further increase customer satisfaction.

H3: The better the service quality provided will further increase customer value.

H4: The better the service quality provided will further increase customer confidence.

H5: The better the corporate image will further boost customer satisfaction.

H6: The better the corporate image will further increase customer trust.

H7: The better the customer value will increasingly customer trust.

H8: The better the customer value will further increase customer.

H9: The better the higher the level of customer satisfaction will increase customer trust.

\section{Research design}

\section{Methodology}

This research is explanatory research is research conducted with a view explaining the relationship between variables through hypothesis testing. The data collection was done by a survey to obtain factual information.

\section{Population and Sample}

The unit of analysis in this study is a non-commercial customer group or groups of households. Total non-commercial customers PDAM Tirta Siak Pekanbaru as many as 12913 households, while PDAM Tirta Dharma Bengkalis as many as 10042 households. The number of samples based on the opinions Roscoe (Sekaran, 2000) that the sample size is greater than 30 and less than 500 have been sufficient to be used in all studies. Referring to the opinion of the Roscoe, the number of samples in this study were 400 respondents from population groups of non-commercial customers in PDAM Tirta Siak Pekanbaru and PDAM Tirta Dharma Bengkalis. Technical sampling used proportional simple random sampling. Proportionally the number of samples of each PDAM then set as follows:

- PDAM Tirta Siak Pekanbaru: 12 913/22 955 x $400=225$ customers (return 204)

- PDAM Tirta Dharma Bengkalis: 10 042/22 955 x $400=175$ customers (return 173).

The total quetioners that return are 373. After the verification of eligibility questionnaire, the samples used in this study were 350 respondents.

\section{Data analysis technique}

Data analysis technique in this research using Structural Equation Model (SEM) using AMOS program package. The use of SEM analysis allows an analysis of a series of relations simultaneously to provide statistical efficiency (Hair et al., 1998).

\section{Effect of Quality of Service to Corporate Image}

\section{Result and Discussion}

Statistical hypothesis testing we concluded that the quality of service PDAM in Riau and positive effect on the company's image in the eyes of the customer PDAM. Hypothesis test results indicate that if the customer perceived service quality is good, the quality of good service the potential to create a good impression or image of the company in the eyes of its customers. Edvardsson, et al., (1994) produces a high quality of service and customer satisfaction helps to spread a positive image in the market. Serkan and Gökhan (2005) in Chreang (2007) states that the company's image is derived from all the experiences that consumers use, while the quality 
of service is a function of experience consumer. Services received can influence better or worse image of the company depends on the quality of service companies, Therefore, the company's image is directly influenced by the perception of the customer the quality of service. Chreang (2007), found a positive and significant influence between service quality and corporate image. These results are consistent with research conducted Chreang (2007) which shows that the model of the relationship of service quality to the company's image is positive and significant.

\section{Effect of Service Quality on Customer Satisfaction}

The hypothesis testing found that service quality and significant positive effect (significant) towards customer satisfaction. Indicating that the better the quality of services provided, the further increase customer satisfaction. Some researchers have studied the relationship between the two constructs quality of service quality and customer satisfaction. Cronin and Taylor (1992) stated that performance and service quality is the cause of customer satisfaction. Customer satisfaction is conceptualized as a fulfillment service to receive a response affective (Oliver, 1997). Therefore, cognitive perceptions on service quality are logically precedes affective ratings of satisfaction (Cronin and Taylor, 1992). Ennew and Binks (1999) in Chreang (2007) found support by making an empirical perspective to the behavior of buyers and sellers. As a result, they found that the quality of service is the antecedent variables of satisfaction and serves as the main elements that influence satisfaction (Bloemer et al., 1997). Parasuraman et al., (1985) conducted a study servqual as the theoretical basis for the relationship between service quality and customer satisfaction.

These results are consistent with research Choi et al., (2002), Chreang (2007), Ching (2008) and Hung (2009), which shows the relationship model of service quality to customer satisfaction is positive and significant.

\section{Effect of Service Quality on Customer Value}

The hypothesis testing found that service quality has significant positive effect to customer's value. It's means that the better the quality of service provided to further improve customer value. Perception of service quality is one of more important issues in generating customer value (Cronin et al., 1997). Srinivas et al., (2004) in Chreang (2007) argues that customer value creation is claimed to be an important factor in the long term. In addition, the positive relationship between service quality and perceived value is supported by a number of studies in defining the service. This means that the positive perception on the quality of service tends to increase the perceived emotional value.These results are consistent with studies and Lindestad Andreassen (1997), Chreang (2007) and Ching (2008) which showed that the model of the relationship of service quality on customer value is positive and significant.

\section{Influence of Corporate Image on Customer Confidence}

The hypothesis testing found that the company's image and no significant negative effect (not significant) against the customer's trust. As described earlier, the company designed the identity for forming the image in the community. Identity is a way Companies presenting himself to the public. The image is a public perception of the company. Consumers form the image of the company based on information associated with the company. Content received will affect the image. According to the theory of identity, the image can be converted into trust in others through the mechanism of "self verification" (Burke and Stets, 1999) in Lin (2007). Smeltzer (1997) in Lin (2007) showed that the influence of the supplier and the buyer interconnected with confidence through the identification of psychological, images, and feelings about the reputation. Selnes (1998) in Lin (2007) states that trust is strengthened when the ability of buyers to identify suppliers. These results do not support the study Lin (2007) and Yuan (2009) which states that the company's image positive and significant impact on customer confidence.

\section{Effect of Customer Value to Customer Satisfaction}

The hypothesis testing found that customers value and significant positive effect (significant) towards customer satisfaction. High-low means that customers value greatly affects the high-low customer satisfaction. Thus, if the value of the customer or the customer advantages in getting low, the service will result in low customer satisfaction. Fornell et al., (1996) identified that customer satisfaction is the result of the perception of customer value, in other words, the value of an element of customer satisfaction showed a positive association between customer value and satisfaction. The value significantly influence consumer purchasing decisions. Kotler (1999) found a close relationship between customer value and customer satisfaction and customer satisfaction measurement should be done from a value perspective. An experimental study of the telecommunications industry conducted by Wang et al., (2004) in Chreang (2007) explores the relationship between service quality, value, satisfaction and behavioral intentions and found that customers perceived value has a significant and direct relationship with satisfaction. These results are consistent with studies Chreang 
(2007), Chong (2008), Cheng et al., (2008) and Hung (2009) which states that the value of the customer relationship model to the satisfaction pelanggan`adalah positive and significant.

\section{Effect of Customer Value the Customer Trust}

The hypothesis testing found that customers value and significant positive effect (significant) against the customer's trust. If the value of the customer or the customer advantages in getting low, the service will result in low customer confidence. Gallarza and Saura (2006) stated that the concept of customer value is based on two key dimensions of consumer behavior, namely: economic dimension (values associated with the perception of the price or value of the transaction), and the psychological dimension (what actually influences the choice of product / service: whether the emotional aspects or more on aspects of cognitive / rational). These results are consistent with research Mehdi et al., (2011) which states that the value of the customer relationship model of the trust of customers is positive and significant.

Effect of Customer Satisfaction to Customer Confidence Testing of the hypothesis found that customer satisfaction has positive and meaningful (significant) towards our customers' confidence in Riau Province PDAM. Means that if the customer satisfied by PDAM the potential to increase our customers' confidence PDAM in Riau Province. Trust in the person or organization previously obtained by observing the interaction, such as conflict, with others in the same situation (Holmes, 1991) in Sabiote (2002). From an empirical perspective, studies Garbarino and Johnson (1999) in consumer behavior, Ganesan (1994) supports the findings about the relationship between customer satisfaction with the organization and trust in the organization. Because it is directly related to expectations, satisfaction from time to time will strengthen the reliability of the company in contributing to believe.

These results are consistent with the research Achim (2002) and Javadein et al., (2008) which states that the relationship model of customer satisfaction on customer confidence is positive and significant. Effect of Customer Satisfaction to Customer Confidence Testing of the hypothesis found that customer satisfaction has positive and meaningful (significant) towards our customers' confidence in PDAM Riau Province. It's means that if the customer satisfaction by PDAM the potential to increase our customers' confidence of PDAM in Riau Province.

Trust in the person or organization previously obtained by observing the interaction, such as conflict, with others in the same situation (Holmes, 1991) in Sabiote (2002). From an empirical perspective, studies Garbarino and Johnson (1999) in consumer behavior, Ganesan (1994) supports the findings about the relationship between customer satisfaction with the organization and trust in the organization. Because it is directly related to expectations, satisfaction from time to time will strengthen the reliability of the company in contributing to believe. These results are consistent with the research Achim (2002) and Javadein et al., (2008) which states that the relationship model of customer satisfaction on customer confidence is positive and significant.

\section{Conclusion}

1. Service Quality is well received and perceived customer a good impression for the company. Customers feel satisfied if the quality of service received and perceived in line with expectations and desires. Good service quality gives good value for the customer in accordance with the sacrifices it has made customers such as cost, time, energy and thoughts. Customers today expect and want a higher quality of service and will give high appreciation of the product / service of the quality of services provided.

2. Satisfaction perceived service customers can build a good image for the company. The company's desire to enhance customer confidence if it is not accompanied by imaging products / services that are good in the eyes of customers giving the impression is not good for the customer.

3. Compliance with the value of the sacrifices made by customers, keep customers satisfied and strives to remain a customer and use the products / services of the company. Customers expect value which is a form of sacrifice that has made the customers to get the products / services produced by the company worth the effort that has been done.

4. Customer trust is determined by customer satisfaction in consuming products / services. Satisfied customers in consuming products / services that the company provides great expectations and provide high confidence in the company.

\section{Suggestion}

1. PDAM must pass an increase in employee training programs that focus on how to serve customers well and the handling of customer complaints.

2. PDAM should increase positive word of mouth customers as strategies to enhance the image and customer trust through improved service quality 
3. Demands for customers with the high quality of service must be addressed immediately by PDAM by making a real effort to improve the service quality improvement performance against customer complaints handling, in the face of customer friendliness and accuracy of the information related to a service interruption.

\section{References}

[1] Abadi Yusuf Hidayat, (2007), Pengaruh Kualitas Layanan Terhadap Kepuasan Pelanggan, Citra Perusahaan Dan Loyalitas Pelanggan Pada Perusahaan Jasa, Fakultas Ekonomi, Ilmu Manajemen, Pasca Sarjana, Universitas Brawijaya, Malang

[2] Achim Walter, (2002), The Impact of Satisfaction, Trust, and Relationship Value on Commitment:Theoretical Considerations and Empirical Results, University of Karlsruhe, GERMANY

[3] Anderson and Srinivasan (2003), E- Satisfaction and E-Loyalty: A Contingency Framework, Psychology \& Marketing, Vol. 20(2): $123-138$

[4] Anderson, J.C. and Narus, J.A. (1990): "A model of distributor firm and manufacturer firm working partnerships", Journal of Marketing Research, Vol. 54, No. 1, pp. 42-58

[5] Andreassen. TW and Lindestad. B (1997), Customer Loyalty and Complex Services: The Impact of Corporate Image on Quality, Customer Satisfaction and Loyalty for Customers with Varying Degrees of Service Expertise, The International Journal of Service Industry and Management, Vol. 8, No 4

[6] Atillaoglu (2007), Key drivers of customer loyalty in a bank portal context, Master Thesis Industrial Engineering and Management Science Faculty of TechnologyManagement Department of Quality and Reliability Engineering Eindhoven University of Technology

[7] Azman Ismail; Muhammad Madi Bin Abdullah; Sebastian K. Francis (2009),Exploringthe relationships among service

[8] quality features, perceived value and customer satisfaction, Journal of Industrial Engineering and Management

[9] Bei, Lien-Ti, Shang, Cian-Fong, (2006), Building marketing strategies for state-owned enterprises against private ones based on the perspectives of customer satisfaction and service quality, Journal of Retailing and Consumer Services, 13: 1-13

[10] Berry LL, Zeithaml VA, Parasuraman, (1985), A. Quality counts in services too. Bus Horiz ; $28: 44$ - 52 (May/June)

[11] Berry, L. , Parasuraman, A. and Zeithaml V. (1994). "Improving Service Quality in America: Lessons Learned, Academy of Management Executive

[12] Berry, L.(1995). "Relationship marketing of services-growing interest, emerging perspectives", Journal of the Academy Marketing Science, Vol. 23 No. 4, pp.236-45

[13] Bloemer, J., Ruyter, K. \& Pascal, P. (1998). Investigating drivers of bank loyalty: the complex relationship between image, service quality and satisfaction. International Journal of Bank Marketing, 16(7): pp. 276-286

[14] Buttle, Francis (2007), Customer Relationship Management (Manajemen Hubungan Pelanggan), Concept and Tools, alih bahasa Arief Subiyanto, Bayumedia Publishing, Jakarta

[15] Badan Pendukung Pengembangan Sistem Penyediaan Air Minum (BPPSPAM) Tahun 2008

[16] Bilal Afsar, Zia Ur Rehman, Jaweria Andleeb Qureshi and Asad Shahjehan. (2010), Determinants of customer loyalty in the banking sector: The case of Pakistan, African Journal of Business Management Vol.4 (6): pp. 1040-1047

[17] Bitner, M.J. (1990). Evaluating Service Encounters: The Effects of Physical Surroundings and Employee Responses. Journal of Marketing, 54 (April): 69-82

[18] Caceres, R.C. \& Paparoidamis, N.G. 2007,'Service quality, relationship satisfactions, trust, commitment and business-to- business loyalty', European Journal of Marketing, vol. 41, no. 7/8: pp. 836-67

[19] Caruana. Money. H. Arthur, Berthon. R. Pierre (2000), Service quality and satisfaction - the moderating role of value, European Journal of Marketing, Vol 34: pp. 1338-1352

[20] Cater, Barbara; Zabkar, Venna, (2008), Antecedents and consequences of commitment in marketing research services : the client perspective, Industrial Marketing Management, Article in Press

[21] Chang Kim dan Renee Mauborgne (2005), Blue Ocean Strategy, Harvard Business School Publishing, Boston, Terjemahan, Satrio Wahono, Penerbit PT Serambi Ilmu Alam Semesta Jan 2006

[22] Cheng, L.C.F. Lai, A.C.L. Yeung (2008), The Driving forces of Customer loyalty: a study of internet service Providers in Hong Kong. International Journal of E-Business Research, 4(4): 2-42, October-December 2008

[23] Ching-Fu Chen (2008), Investigating structural relationships between service quality, perceived value, satisfaction, and behavioral intentions for air passengers: Evidence from Taiwan, Elsevier Ltd, Transportation Research Part A Vol 42, 2008: pp 709-717

[24] Chumpitaz R and Swaen Valérie (2004), Service quality and marketing performance in business-to- business markets: exploring the mediating role of client satisfaction, Emerald Group Publishing; Managing Service Quality, Vol 14, No 2/3: pp 235- 248

[25] Choi, Kui-Son, Cho, Woo-Hyun, Lee, Sunhee, Lee, Hanjoon, Kim, Chankon,(2002), The relationship among quality, value, satisfaction, and behavioral intention in health care provider choice : A South Korean study, Journal of Business Research, 57, pp:913-921

[26] Chong Hui Ling (2008), Relationships Between Customer Satisfaction And Service Loyalty: Users'PerceptionOn TelecommunicationService Providers In Malaysia, University of Malaya

[27] Chreang Samphors (2007), Evaluating Service Quality, Customer Value, Corporate Image, Customer Satisfaction and Behavioral Intentions for Mobile Services in Cambodia, Master Thesis In National Cheng Kung University

[28] Christopher Gan, David Cohen, Mike Cleme, Esther Chong (2006), A Survey of Customer Retention in the New Zealand Banking Industry, Banks and Bank Systems/ Volume 1, Issue 4, 2006

[29] Chung-Hao Chen (2009), Development of A Model to Measure Customer Satisfaction with International Tourist Hotel in Taiwan, A Dissertation In HospitalityAdministration Texas Tech University

[30] Corritore C, Kracher B, \& Wiedenbeck S. (2003). On-line trust: Concepts, evolving themes, a model. International Journal of Human Computer Studies, 58: 737-58

[31] Cronin JJ, Taylor SA (1992), Measuring service quality: a re-examination and extension. J Mark;56: 55 - 68 (July)

[32] Cronin JJ, Taylor SA (1994). SERVPERF versus SERVQUAL: reconciling performancebasedandperceptions-minus-expectations measurement of service quality. J Mark;58(1): $125-31$

[33] Cronin JJ, Brady MK, Brand RR, Hightower R, Shemwell DJ (1997), A crosssectional test of the effect of conceptualization of service value. J Serv Mark ;11(6): 375-91

[34] Crosby, L.A., Evans, K.A. \& Cowles, D. 1990, 'Relationship quality in services selling: An interpersonal influence perspective.' Journal of Marketing, vol. 54 (July), no. 3:pp. 68-81

[35] Dedeke. Adenekan (2003), Service quality: a fulfilment-oriented and interaction-centered approach, Emerald Group Publishing; Managing Service Quality, Vol 13, No 4: pp 276-289 
[36] Dick, A.S. \& Basu, K. 1994, 'Customer loyalty: Toward an integrated conceptual framework' Journal of the Academy of Marketing Science, vol. 22, no. 2: pp. 99-113

[37] Doney, P. \& Cannon, J., 1997. An Examination of the Nature of Trustin Buyer-Seller Relationships, Journal of Marketing, 61(1): 35-51.

[38] Edvardsson, B. 2005. Service quality: beyond cognitive assessment. Managing Service Quality 15 (2):127-31.

[39] Ferdinand, A. 2000. Structural Equation Modelling Dalam Penelitian Manajemen. BP-UNDIP, Semarang

[40] Fornell, C. (1992). A national customer satisfaction barometer: The Swedish experience. Journal of Marketing, 56(1): 6-21

[41] Fornell, C., Johnson, M. D., Anderson, E. W., Cha, J., \& Bryant, B. E. (1996). The American customer satisfaction index: Nature, purpose, and findings. Journal of Marketing, 60(4): 7-18

[42] Fornell, C., \& Larcker, D. F. (1981). Evaluating structural equations models with unobservable variables and measurement error. Journal of Marking Research, 18: 39-50

[43] Gallarza, Martina G; Saura, Irene Gil, (2006), Value dimensions, perceived value, satisfaction and loyalty: an investigation of university students' travel behaviour, Tourism Management, 27: 437-452

[44] Ganesan, S., 1994. Determinants of long- term orientation in buyer-seller relationships. Journal of Marketing, 58(April): 1-19

[45] Garbarino, E. \& Johnson, M.S. 1999, 'The different roles of satisfaction, trust, and commitment in customer relationships', Journal of Marketing, vol. 63: pp. 70-87

[46] Gefen, D., 2002. Customer Loyalty in E-Commerce, Journal of the Association for Information Systems, 3: 27-51

[47] Goode, M.M.H. and Harris, L.C. (2007). Online behavioural intentions: An empirical investigation of antecedents and moderators. European Journal of Marketing, Vol. 41 No. 5/6: pp. 512-536

[48] Grönroos, C., F. Heinonen, K. Isoniemi dan M. Lindholm (2000), "The Netoffer Model: A Case Example from the Virtual Marketspace,'Management Decision, Vol. 38, No. 4: 243-252

[49] Gronroos, C. (1984). A service quality model and its market implications. European Journal of Marketing, 18(4): 36-44

[50] Hair, J. F., Anderson, R. E., Tatham, R.L., \& Black, W. C. (1998). Multivariate data Analysis (5th Ed.). New Jersey: Prentice Hall Inc. Harris, Lloyd C and Goode, Mark H, (2004), The four levels of loyalty and pivotal role of trust : a study on online service dynamics, Journal of Retailing, 80: pp.139 - 158

[51] Hennig-Thurau, T. (2000) 'Relationship marketing success through investments in customers', in Hennig-Thurau, T. and Hansen, U. (eds), Relationship Marketing: GainingCompetitive Advantage Through Customer Satisfaction and Customer Retention, Berlin, Springer, pp. 127- 46

[52] Hennig-Thurau, T., Gwinner, K.P. \& Gremler, D.D.2002, Understanding relationship marketing outcomes: An integration of relational benefits and relationship quality. Journal of Service Research, vol. 4, no. 3: pp. 230-47

[53] Hou, Yonghai, (2005), Service Quality of Online Apparel retailers and it's impact on Customer Satisfaction, Trust and Loyalty, Dissertation, Faculty of the Graduate School at the University of North Carolina at Greensboro

[54] Hung-Che Wu, (2009), “An Empirical Study of Behavioural Intentions in The Taiwan Hotel Industry”, Thesis, Lincoln University

[55] Hutchinson, Joe; Lai, Fujun; Wang, Youcheng, (2009), Understanding the relationships of quality, value, equity, satisfaction and behavioral intentions among golf travelers, Tourism Management, 30: pp.298- 308

[56] Imam Ghozali. (2001). Aplikasi Analisis Multivariat Dengan Program SPSS,BP Universitas Diponegoro, Semarang

[57] Javadein, S. R., Khanlari, A. Estiri, M. (2008), Customer loyalty in the sport services industry: the role of service quality, customer satisfaction, commitment and trust, International Journal of Human Sciences Volume: 5 Issue: 2 Year: 2008

[58] Kotler, P. 1999, Marketing for hospitality and tourism, 2nd edn, Prentice Hall, Upper Saddle River, N.J

[59] Kyung Hoon Kim, Kang Sik Kim, Dong Yul Kim, Jong Ho Kim, Suk Hou Kang (2006), Brand equity in hospital marketing, Elsevier Inc Journal of Business Research, Vol 61, 2008: pp 75-82

[60] Lau, G. T. \& Lee, S. H., 1999. Consumer Trust in a Brand and the link to Brand Loyalty. Journal of market Focused Management, 4(4): 341-390.

[61] Lemmink, Joseph dan Jan Mattsson, 2003. "Employee Behavior, Feelings of Warmth and Customer Perception in Service Encounters," International Journal of Retail \& Distribution Management, Vol. 30, No: 1

[62] Lin, Long-Yi (2007), The Influence of Corporate Image, Relationship Marketing, and Trust on Purchase Intention: The Moderating Effects of Word-of- Mouth, School of Management Sciences, Aletheia University, Taipei, Taiwan, ROC

[63] Mac Millan, Keith; Money, Kevin and Downing, Steve (2005), Relationship marketing in the non-profit sector : an extension and application of the commitment-trust theory, Journal of Business Research, 58: 806-818

[64] Malhotra, N.K., Hall, J., Shaw, M. \& Crisp, M. 1996, Marketing research: An applied orientation, Prentice Hall, Sydney.

[65] Malhotra, N. K., F. M. Ulgado, J. Agarwal, G. Shainesh, and L. Wu. 2004. Dimensions of service quality in developed and developing economies: multi- country cross-cultural comparisons. International Marketing Review 22 (3): 256-78

[66] Normann, R. (1991). Service management: Strategy and leadership in service business. New York: John Wiley and Sons.Nunnally, J. C. 1978. Psychometric theory.New York: McGraw-Hill.

[67] Oliver, R.L. 1980, 'A Cognitive model of the antecedents and consequences of satisfaction decisions', Journal of Marketing Research, vol. 17, no. 4: pp. 460-9

[68] Oliver, R.L. \& DeSarbo, W.S. 1988, 'Response Determinants in Satisfaction Judgments', Journal of Consumer Research, vol. 14, no. 4: pp. 495-507

[69] Oliver, R.L. \& Rust, R.T. 1997, 'Customer Delight: Foundations, Findings, and Managerial Insight', Journal of Retailing, vol. 73, no. 3: pp. 311-36

[70] Oliver, R. L. 1997. Satisfaction: A behavioral perspective on the consumer. New York: McGraw- Hill

[71] Orth, Ulrich R; Green, Mark T, (2008), Consumer loyalty to family versus non-family business : the roles of store image, trust and satisfaction, Journal of Retailing and Consumer Service, Article in Press

[72] Parasuraman, A., Zeithaml, V. A., \& Berry, L. L. (1985). A conceptual model of service quality and its implications for future research. Journal of Marketing, 49: 41-50

[73] Parasuraman, A., Berry, L.L. \& Zeithaml, V.A. 1991, 'Understandingcustomer expectations of service', Sloan Management Review, vol. 32, no. 3: pp. 39-48

[74] Parasuraman, A. 1991, Marketing research, 2nd edn, Addison- Wesley Pub. Co., Reading, Mass

[75] Petrick, J. F. (2004). The role of quality, value, and satisfaction in predicting cruise passengers' behavioral intentions. Journal of Travel Research, 42: 397- 407

[76] Pizam and Ellis, T (1999), Customer satisfaction and its measurement in hospitality enterprises, International Journal of Contemporary Hospitality Management, p 326-339

[77] Phillips, Marlene J, (2005), The impact of organization culture on the perceived quality of service delivery, Dissertation, School of of Business and Entrepreneurship Nova Southern University. 
[78] PP No. 16 Tahun 2005 tentang Pengembangan Sistem Penyediaan Air Minum

[79] Ravichandran; Bhargavi; Arun Kumar (2010), Influence of Service Quality on Banking Customers' Behavioural Intentions, International Journal of Economics and Finance, Vol. 2, No. 4

[80] Reicheld, F.F dan P. Schefter (2000), "E- Loyalty: Your Secret Weapon on the Web," Havard Business Review: 105-113

[81] Ribbink, D., Riel, A., Liljander, V. and Streukens, S. (2004), Comfort your online customer: Quality, trust, and loyalty on the Internet, Managing Service Quality, 14(6): 446-456

[82] Robert Juran (1998), Marketing Research \& Aplied Orientation, New Jersey Prentice Hall

[83] Roger D. Backwell, Paul W Miniard, James F. Engel, (1990), Consumber Behavior,Chicago: Dryden Press

[84] Ruben Chumpitaz C. And Valérie Swaen (2002), Service Quality andBrand Loyalty Relationships: Investigating the Mediating effect of Customer Satisfaction, $31^{\text {st }}$ Conference of European Marketing Academy May 2002

[85] Ruyter, K., Wetzels, M. and Bloemer, J. (1998). On the relationship between perceived service quality, service loyalty and switching costs. International Journal of Service Industry

[86] Sabiote and Nicolás (2002), Social Regard: Effects on the Relationship Customer-Service Organization.University of Murcia, Spain

[87] Schein, E.H. 1992, Organisational culture and leadership, 2nd edn, CA: Jossey-Bass Publishers, San Francisco

[88] Sekaran, Uma, (1999), Research Methods For Business, A Skill - Bulding Approach, Third Edition, John Wiley \& Sons, Inc.

[89] Sekaran Uma, (2006) Metodologi Penelitian Untuk Bisnis, Edisi Pertama, Salemba Empat

[90] Shih, Ching-he, (2006), Effect of culture on service quality and customer satisfaction ratings, Dissertation, Department of Parks, Recreation and Tourism, The University of Utah, May

[91] Singh, J. \& Sirdeshmukh, D. 2000, 'Agency and trust mechanisms in consumer satisfaction and loyalty judgements', Journal of the Academy of Marketing Science, vol. 28, no. 1: pp. 150-167

[92] Smith, A.K. and Bolton, R.N. 1998, An experimental investigation of customer reactions to service failure and recovery encounters, Journal of Service Research, Vol. 1 No. 1: pp. 65-81

[93] Undang-Undang No.7 Tahun 2004 tentang Sumber Daya Air

[94] Zeithaml, V. A., Parasuraman, A. and Berry, L. L (1990), "Delivering Quality Service Balancing Customer Perceptions and Expectation" New York: The FressPress. 